fragments of $[\mathrm{M}\{\mathrm{O} 1-\mathrm{N} 1-\mathrm{C} 1(\mathrm{~N} 3)-\mathrm{C} 2(\mathrm{~N} 4)-\mathrm{N} 2-\mathrm{O} 2\}]$. In order to understand the role of metal in the channel formation the intermolecular metal-chains interaction energies have been calculated according to the empirical consistent valence force field (CVFF).

[1] Gümüş G., Ahsen V., Lebrun C., Luneau D., Pécaut J., New. J. Chem., 2004, 28, 177.

\section{MS13 P24}

Self-assembled fullerene-rich stannoxane derivatives Carine Duhayon, Uwe Hahn, A. Gégout, Y. Coppel, A. Saquet, J.-F. Nierengarten Laboratoire de Chimie de Coordination du CNRS, 205 route de Narbonne, 31077 Toulouse Cedex, France. E-mail: duhayon@lcc-toulouse.fr

\section{Keywords: Organooxotin, Self-assembly, Fullerene}

Organooxotin cages have received considerable attention in view of their structural diversity [1]. Importantly, these compounds can be self-assembled in almost quantitative yields under very mild reaction conditions. Therefore, organotin chemistry appears to be an attractive tool for the preparation of multi-functional nanostructures. Indeed, Chandrasekhar and co-workers have already reported the self-assembly of a robust, thermally stable hexaferrocene assembly in quantitative yield by reaction of $n$ butylstannonic acid with ferrocene monocarboxylic acid [2]. By using a similar approach, the same group has also described the synthesis of a hexaporphyrin assembly with promising DNA cleavage activity [3]. Herein, we show that $\mathrm{C}_{60}$ derivatives bearing a carboxylic acid function undergo self-assembly with n-butylstannonic acid $(\mathrm{nBuSn}(\mathrm{O}) \mathrm{OH})$ to produce fullerene-rich nanostructures with a stannoxane core in nearly quantitative yields. The reaction conditions have been first tested with several model compounds and the structure of the stannoxane core confirmed by X-ray crystal structure analysis.

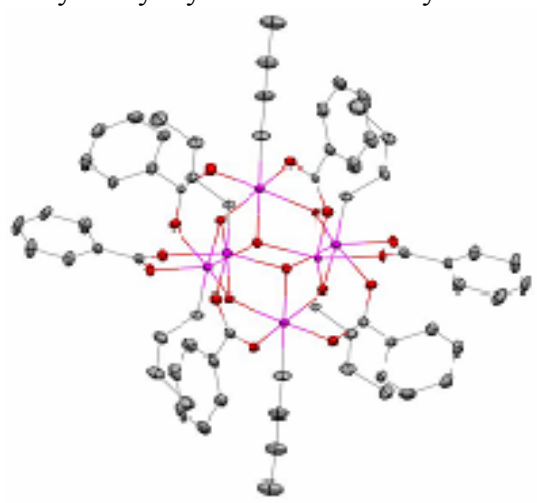

Further investigations with fullerene derivatives have also been successful. The fullerene-rich derivatives were obtained in quantitative yields and their structure confirmed by the observation of a single resonance in their ${ }^{119} \mathrm{Sn}$ NMR spectra [4]. The self-assembly of fullerenecontaining components reported herein is an efficient tool for the preparation of fullerene-rich nanostructures. Such compounds are thus easier to produce and the range of systems that can be prepared is not severely limited by the synthetic route. In this way, in-depth investigations of their properties is possible and one can really start to envisage the use of fullerene-rich materials for specific applications.

[1] V. Chandrasekhar, S. Nagendran and V. Baskar, Coord. Chem. Rev., 2002, 235, 1.
[2] V. Chandrasekhar, S. Nagendran, S. Bansal, M. A. Kozee and D. R. Powell, Angew. Chem. Int. Ed., 2000, 39, 1833.

[3] V. Chandrasekhar, S. Nagendran, R. Azhakar, M. Ravikumar, A. Srinivasan, K. Ray, T. K. Chandrashekar, C. Madhavaiah, S. Verma, U. D. Priyakumar and G. N. Sastry, J. Am. Chem. Soc., 2005, 127, 2410.

[4] U. Hahn, A. Gégout, C. Duhayon, Y. Coppel, A. Saquet, J.-F. Nierengarten, Chem. Commun. 2007, 516.

\section{MS13 P25}

Copper(II) halide complexes with simple pyridine based alcohols. Ivan Leban and Nina Lah, Faculty of Chemistry and Chemical Technology, University of Ljubljana, Askerceva 5, 1000-Ljubljana, Slovenia;

E-mail: ivan.leban@fkkt.uni-lj.si

Keywords: $\mathrm{Cu}$ (II) coordination polymer, alkoxide, pyridine alcohol ligands

Reactions of $\mathrm{Cu}(\mathrm{II})$ halides $\left(\mathrm{CuCl}_{2}\right.$ and $\left.\mathrm{CuBr}_{2}\right)$ with simple pyridine based alcohols: (2-hydroxymethyl)-pyridine, (2hydroxyethyl)-pyridine and (2-hydroxypropyl)-pyridine afford a series of new $\mathrm{Cu}(\mathrm{II})$ alkoxide complexes, all having a similar dinuclear $\mathrm{Cu}_{2} \mathrm{O}_{2}$ structural motif [1]. The structures of six new complexes will be presented, spanning diverse architectures from discrete dinuclear complex $\quad\left[\mathrm{Cu}_{2} \mathrm{~L}_{2} \mathrm{Br}_{2}\right]$, an ionic compound $\left[\mathrm{Cu}_{2} \mathrm{Cl}_{2}(\mathrm{HL})_{4}\right] \mathrm{Cl}_{2} \cdot 2 \mathrm{H}_{2} \mathrm{O}$, to two tetranuclear complexes of a defect dicubane-like type structure, $\left[\mathrm{Cu}_{4} \mathrm{~L}_{4} \mathrm{Cl}_{4}\right]$ and $\left[\mathrm{Cu}_{4} \mathrm{~L}_{4} \mathrm{Br}_{4}\right]$ and two polymeric chain compounds with the $\left[\mathrm{Cu}_{2} \mathrm{~L}_{2} \mathrm{Cl}_{2}\right]_{\mathrm{n}}$ and $\left[\mathrm{Cu}_{2}(\mathrm{HL})_{2} \mathrm{Cl}_{4}\right]_{\mathrm{n}}$ composition (L and $\mathrm{HL}$ are deprotonated and neutral forms of simple pyridine alcohol ligans). In addition to the synthesis and structural description, their magnetic properties will be presented and correlated with their structural features.

Additionally, the crystal structures of two mononuclear compounds of the $\mathrm{CuBr}_{2}(\mathrm{HL})_{2}$ and $\left.\mathrm{CuBr}(\mathrm{HL})_{2}\right] \mathrm{Br}$ will be also presented.

The financial support through grant P1-0175 and X-2000 of Slovenian Research Agency and MVZT is gratefully acknowledged.

[1] Lah, N., Leban, I. \& Clérac R., Eur. J. Inorg. Chem., 23, 2006, 4888-4894.

\section{MS13 P26}

Benefits of X-ray on Characterization of vic-Dioxime Nickel(II) Complexes Fatma Yuksel ${ }^{\mathrm{a}, \mathrm{b}}$, Ayse Gul Gurek ${ }^{\mathrm{a}}$, Erwan Jeanneau ${ }^{\mathrm{b}}$, Ilke Gurol ${ }^{\mathrm{c}}$, Mahmut Durmus ${ }^{\mathrm{a}}$, Dominique Luneau ${ }^{\mathrm{b}}$, Vefa Ahsen ${ }^{\mathrm{a}, \mathrm{c}}$. ${ }^{\mathrm{a}}$ Gebze Institute of Technology, Turkey. ${ }^{\mathrm{b}}$ Université Claude Bernard Lyon 1, France ${ }^{\mathrm{c}}$ TUBITAK-Marmara Research Center, Turkey E-mail: fatma@gyte.edu.tr

Keywords: metalloorganic complexes, coordination chemistry, vic-dioxime

vic-Dioximes have been used as chelating agent in coordination chemistry since early 1900s [1-3]. Because of mildly acidic hydroxyl groups and slightly basic nitrogen atoms, vic-dioximes are amphoteric ligands which form square planar, square pyramidal and octahedral complexes with transition metal cations such as nickel (II), copper (II) palladium (II) and cobalt (III) [4-5]. vic-Dioximes give rise to several geometrical isomers. When the molecule is formally symmetric, three forms are possible: anti- $(E, E)$, amphi- $(E, Z)$, and syn- $(Z, Z)$. 